\title{
HELIUM RELEASE FROM 12Cr18Ni10Ti STAINLESS STEEL AFTER IMPACT OF STEADY STATE GLOW DISCHARGE He PLASMA
}

\author{
G.P. Glazunov, M.N. Bondarenko, A.L. Konotopskiy, I.E. Garkusha, \\ S.M. Maznichenko, I.K. Tarasov \\ National Science Center "Kharkov Institute of Physics and Technology", \\ Institute of Plasma Physics, Kharkiv, Ukraine \\ E-mail: glazunov@ipp.kharkov.ua
}

The thermal desorption experiments were carried out to study the process of helium outgassing from the stainless steel $12 \mathrm{Cr} 18 \mathrm{Ni10Ti}$ after exposure to a steady state glow discharge (GD) plasma in He atmosphere. The currentvoltage characteristics in different plasma regimes have been measured and estimation of He ions energy has been made. Measurements of He release from the stainless steel probes showed the saturation of probe surface with He after the fluencies of $\sim 4 \cdot 10^{19} \mathrm{ion} / \mathrm{cm}^{2}$. The value of He outgassing strongly depends on the regime of GD plasma: pressure of work gas, discharge voltage, etc. Several maximums, including the maximum at the temperature of $100 \ldots 150^{\circ} \mathrm{C}$, were registered in the He desorption curves that indicated different He atom states on the surface and in the nearest surface bulk. Physical mechanisms of such He outgassing are discussed.

\section{INTRODUCTION}

Glow discharge plasma cleaning (GDC) in hydrogen, helium, argon atmosphere [1-5] is one of the common wall conditioning procedures in plasma devices. However, along with effective cleaning of the surface from impurities, this method has a number of disadvantages: sputtering and over-sputtering of materials, adsorption and subsequent release of plasmaforming (discharge) gases [5], etc. The discharge gases adsorbed by the wall or by other plasma facing components can then release and serve as an undesirable additive during plasma experiments. Earlier, a completely different $\mathrm{He}$ desorption behavior for different metals after GDC in He was observed in work [3]. Using thermal desorption spectrometer, several maximums in the curve of He desorption from stainless steel (SUS316L) were registered. This indicated that adsorbed $\mathrm{He}$ atoms could be in different states with different binding energies. The nature of desorption process for trapped gases is not fully understood yet. Therefore, the additional information in this field will be useful. Using a thermal desorption pulse method, we carried out the experiments in the small plasma device DSM-1 to study $\mathrm{He}$ retention and release from the stainless steel $12 \mathrm{Cr} 18 \mathrm{Ni} 10 \mathrm{Ti}$ (a material the vacuum chamber of Uragan-2M stellarator was made of) after the impact of helium GD plasma.

\section{EXPERIMENTAL SETUP}

The DSM-1 plasma facility (diagnostic stand of materials) was described in detail in $[6,7]$. The scheme of the experimental setup is shown in Fig. 1. The vacuum chamber is made of the stainless steel 12Cr18Ni10Ti (hereinafter referred to as SS), unheated, and assembled with vacuum rubber and Viton seals. The volume of the chamber is $0.35 \mathrm{~m}^{3}$, the plasma facing wall area is about $0.5 \mathrm{~m}^{2}$. The chamber is pumped by a TMP-500 turbomolecular pump (500 1/s pumping speed) and a NVR-5 (5 l/s) fore vacuum pump.

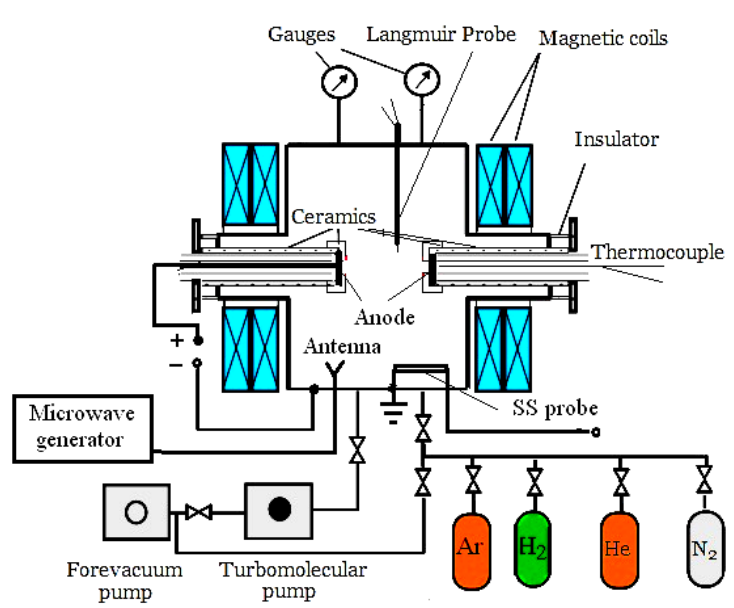

Fig. 1. Scheme of the DSM-1 device

The samples for studies were similar to the thermal desorption probes described in [8-10] used for the measurements of the stainless steel outgassing rate and the number of gas monolayers on its surface in the Uragan-2M stellarator. They are made of $12 \mathrm{Cr} 18 \mathrm{Ni} 10 \mathrm{Ti}$ $\mathrm{SS}$ in form of a plate with dimensions of 200x10x0.3 mm. Before placing the samples in the vacuum chamber they were cleaned with such procedures: fine sandpaper cleaning, wiping with special fabric wetted in clean branded gasoline, drying, wiping with special fabric wetted in $96 \%$ ethanol, drying. The probe was placed on the wall of the DSM-1 vacuum chamber (see Fig. 1). One end of the probe was grounded (connected to the wall, which is a cathode) and another one was connected to a power supply to provide heat of a sample up to the temperature of $700{ }^{\circ} \mathrm{C}$ in stationary or pulse regimes. The anodes (see Fig. 1) were two symmetrically placed discs made of the polished stainless steel $12 \mathrm{Cr} 18 \mathrm{Ni10 \textrm {Ti }}$ with a diameter of $25 \mathrm{~mm}$ and a thickness of $1.5 \mathrm{~mm}$.

After being pumped to the ultimate pressure of $\sim 2 \cdot 10^{-6}$ Torr, the chamber was filled with working gas helium (99.998 vol.\%) injected through the needle valve 
leak to provide a work pressure $\left(4.5 \cdot 10^{-2} \ldots .5 .6 \cdot 10^{-3}\right.$ Torr $)$; then, a steady state GD was switched on. The regimes of the GD during GDC were at an applied potential varied with He pressure within the range of $250 \ldots 369 \mathrm{~V}$ and a discharge current of $150 \mathrm{~mA}$. The length of time of the samples exposure to plasma was $2,6,12$, and $20 \mathrm{~h}$ (fluencies $3.6 \cdot 10^{19} \ldots 3.6 \cdot 10^{20} \mathrm{ion} / \mathrm{cm}^{2}$ ). The currentvoltage characteristics were measured (Fig. 2) in different regimes and He ions energy was estimated (Figs. 3, 4).

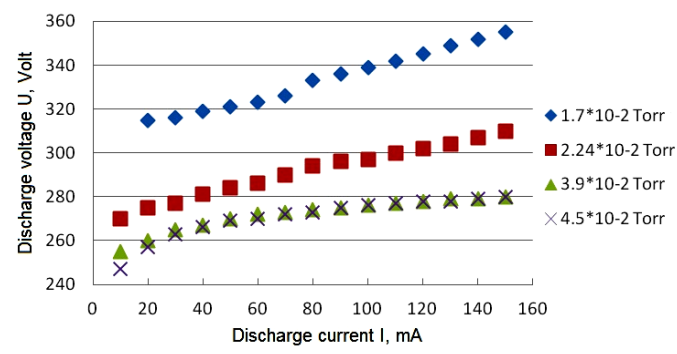

Fig. 2. Current-voltage characteristics of GD at different He pressures

The energy distribution of helium ions was measured with a method described in [11], using multigrid analyzer placed at the level of the chamber wall, which was bombarded with ions. Fig. 3 shows the energy spectrum of $\mathrm{He}^{+}$ions measured at a working gas pressure $1.6 \cdot 10^{-2}$ Torr. With an increase in the working gas pressure, the maximum of the ion energy distribution shifts towards lower energies (see Fig. 4). Then, the sample was remounted from the DSM-1 device. The sputtering yield was measured by the weight loss method using a VLR-200 balance, similar to that described in [7]. Erosion coefficient of the SS 2KH18N10T was $\sim 0.1$ at./ion at the discharge voltage of $320 \mathrm{~V}$. This value of the erosion coefficient corresponds rather well to the literature data on sputtering yield of St316 (an analogue of steel 12Cr18Ni10Ti) under $\mathrm{He}^{+}$ion bombardment with ion energy of $\sim 100 \mathrm{eV}[12,13]$. However, our measurements showed (see Figs. 3, 4) that the main part of the $\mathrm{He}$ ions has energy lower than $100 \mathrm{eV}$. The reason for this discrepancy may be the of a large number of fast charge-exchange atoms, whose sputtering yield is similar to that of ions.

After about a 1-hour exposure on the atmosphere, the SS probe was installed in the special stand GAS (described in [9]) for the measurements of the total outgassing rate and He-release (outgassing) rate. The methods for determining the outgassing rate $q$ of SS and the number of monolayers $N$ of impurity gases on its surface is described in detail in [8-10]. It is noteworthy that after being installed in the stand vacuum vessel, all SS probes were heated together with the chamber walls at the temperature of $100 \ldots 150{ }^{\circ} \mathrm{C}$ during $1 \mathrm{~h}$. This was necessary to obtain a good ultimate vacuum ( $210^{-7}$ Torr) after opening the chamber to the atmosphere and to clean a sample surface from impurities. So, it was important to check whether helium is desorbed at these temperatures. The value of outgassing rate is proportional to a pressure change in the vacuum chamber during pulsed heating of the SS probe to the temperature of $120 \ldots 700{ }^{\circ} \mathrm{C}$.

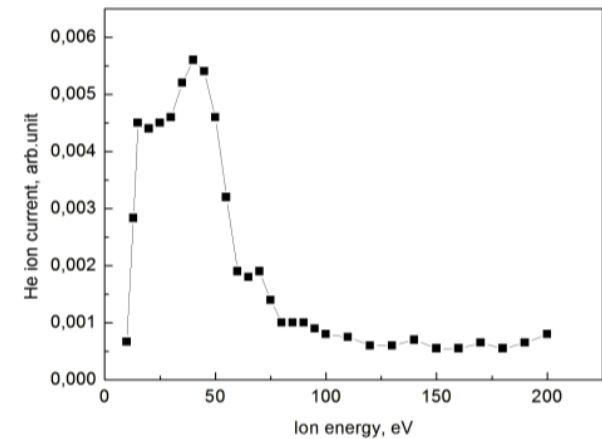

Fig. 3. Energy distribution of $\mathrm{He}^{+}$ions reaching the wall measured at the work gas pressure $1.6 \cdot 10^{-2}$ Torr

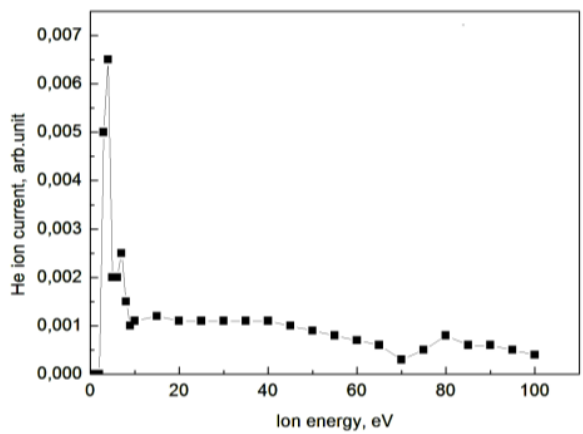

Fig. 4. Energy distribution of $\mathrm{He}^{+}$ions measured at the work gas pressure $2.8 \cdot 10^{-2}$ Torr

The change of a total pressure was measured with the ionization gauges PMI-10-2 and PMI-2. At the same time, He partial pressure was measured with massspectrometer MX-7304. In the first case, the rate of gas release was expressed in (Torr 1$) /\left(\mathrm{s}^{\cdot} \mathrm{cm}^{2}\right)$. In the second one, the results are given in the form of time dependences of the values of the helium ion current (in arbitrary units). For both cases, a pressure increase during the sample heating is proportional to the gas concentration on the metal surface. Therefore, by measuring the pressure increase during desorption, one can say about the kinetics of the behavior of helium under various regimes of GDC. To estimate the percentage of helium released in relation to the total gas outgassing, the MX-7304 mass spectrometer was calibrated according to the data of the PMI-10-2 and PMI-2 ionization gauges. In Figs. 5-7, the apparatus curves show the change in the helium pressure in the measurement chamber of the stand when the sample is pulsed to the temperatures of $120{ }^{\circ} \mathrm{C}$ (see Fig. 5) and $700{ }^{\circ} \mathrm{C}$. For the latter two variants the plots are presented: with (see Fig. 6) and without (see Fig. 7) preheating of the sample at the temperature of $120{ }^{\circ} \mathrm{C}$.

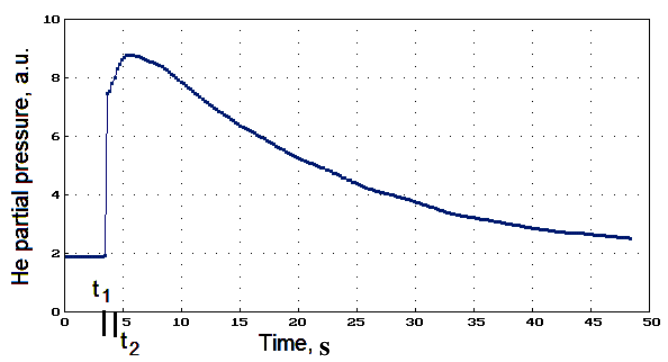

Fig. 5. He release during SS probe pulse (1 s) heating: $t_{1}$-start heating; $t_{2}$ - maximum sample temperature is about $120^{\circ} \mathrm{C}$, switch off heating 


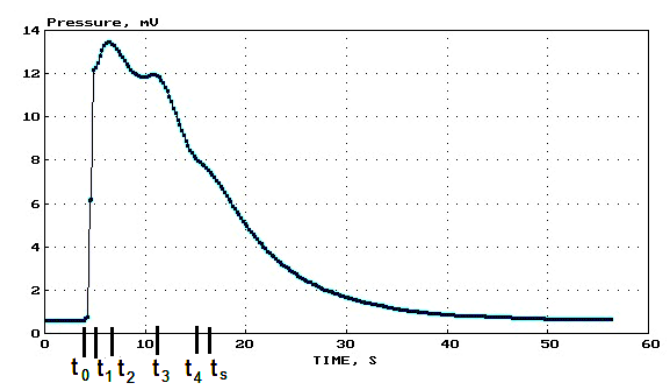

Fig. 6. He release during SS probe pulse heating (12 s, $700^{\circ} \mathrm{C}$ ) after preheating at $120^{\circ} \mathrm{C}$ : sample temperature is about $t_{1}-\sim 120 ; t_{2}-\sim 250 ; t_{3}-\sim 450$;

$t_{4}-\sim 650{ }^{\circ} \mathrm{C} ; t_{0}-$ start of heating; $t_{s}-$ switch off heating

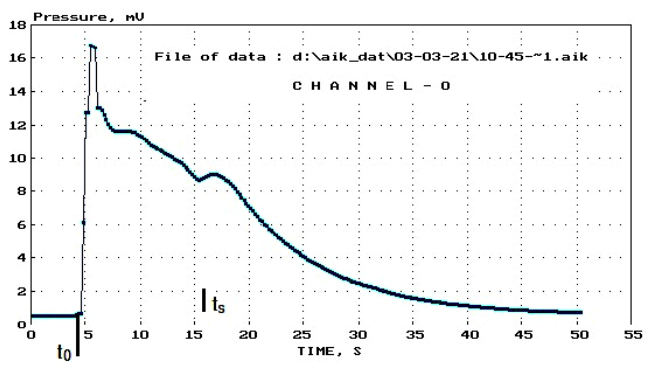

Fig. 7. He release during SS probe pulse heating (12 s) without preheating at $100 \ldots 150^{\circ} \mathrm{C}: t_{0}-$ switch on heating; $t_{s}-700^{\circ} \mathrm{C}$, switch off heating

\section{RESULTS AND DISCUSSION}

Figs. 5-7 show that helium release starts at the temperature lower than $100{ }^{\circ} \mathrm{C}$ and outgassing rate increases almost immediately after switching on heating. The next maximums of $\mathrm{He}$ desorption are observed at the temperatures of $250 \ldots .300 ; \approx 450 \ldots 500$, and $650 \ldots 700{ }^{\circ} \mathrm{C}$. It means that helium is held in the stainless steel in different states with different activation energies of desorption. However, in [3], very low helium release from the SUS316L steel at temperatures of $<150{ }^{\circ} \mathrm{C}$ was detected after GDC in helium. The reason may be in the differences in the surface properties of the studied steels (for example, the degree of contamination) and in the features of the techniques and methods.

Low energy He ions and atoms could be trapped near the metal surface similar to other residual gases such as water vapor, hydrogen, nitrogen, $\mathrm{CO}, \mathrm{CO}_{2}$, etc., forming weak bonds with the molecules of these gases adsorbed in pores and micropores, cracks, and microcracks on the surface of the chamber material. Islands of carbides, nitrides, oxides, various films, etc. can also adsorb some amount of the helium. This helium has very low desorption energy and can be desorbed even at the temperature $<100^{\circ} \mathrm{C}$, as was observed for graphite in [3]. The stainless steel samples used in our experiments have another composition and, possibly, a greater amount of contaminants in the form of carbides, oxides, carbon films, etc., which leads to the appearance of a desorption peak at low temperature, unlike data for the stainless steel SUS316L in work [3]. As Figs. 6, 7 demonstrate, the amount of such He strongly decreases even after one pulse heating to $120{ }^{\circ} \mathrm{C}$. For the full removal of such helium from the sample surface, the standard stationary heating at the temperature of
$100 \ldots 150^{\circ} \mathrm{C}$ of the vacuum chamber together with the sample during one hour is enough.

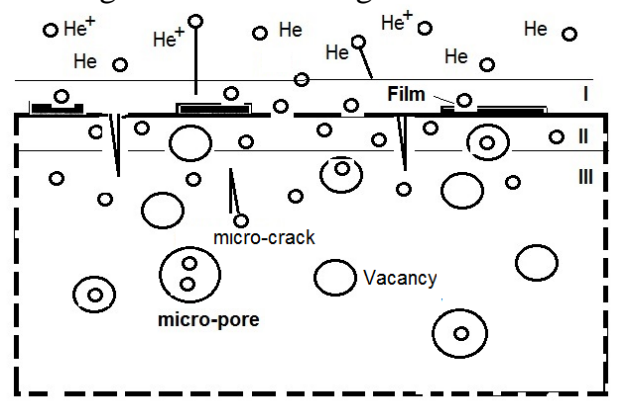

Fig. 8. Different zones of helium trapping by wall: I- low desorption temperatures $\sim 150 \ldots 300^{\circ} \mathrm{C}$;

II-desorption temperatures $\sim 450 \ldots 500{ }^{\circ} \mathrm{C}$;

III - desorption temperatures $\geq 650 \ldots 700^{\circ} \mathrm{C}$

Helium ions with energy $\geq 100 \mathrm{eV}$ and fast neutral $\mathrm{He}$ atoms can be implanted in the nearest surface bulk of metal and can be trapped by different defects and radiation damages (Fig. 8). Such helium requires more energy for desorption $\left(450 \ldots 500^{\circ} \mathrm{C}\right)$. And, finally, during plasma treatment (GDC), part of the implanted ions can diffuse deep into the metal (for example, by the mechanism of the formation of complexes with vacancies $[14,15])$. There helium atoms are bound by lattice defects: vacancies, pores and micropores, microcracks, etc. To remove such helium, the temperatures of $650 \ldots 700{ }^{\circ} \mathrm{C}$ and higher are required.

Thus, the processes of trapping and release of helium from stainless steel are complex, multi-stage, including a number of sequential and parallel reactions (absorption, introduction into the volume of metal, diffusion, desorption, etc.). These processes depend on many factors: the pressure of the plasma-forming gas, ion energy, radiation doses, etc. Conventionally, as Fig. 8 shows, three zones (signed as I, II, and III) of helium trapping by the metal and, accordingly, three different energy states during its desorption could be distinguished.

Fig. 9 shows the rate of outgassing of helium from the stainless steel when heated to $300{ }^{\circ} \mathrm{C}$ as a function of the time of a glow discharge cleaning. It is seen that saturation occurs at times of more than $10 \mathrm{~h}$ (dose $\approx 4 \cdot 10^{19} \mathrm{ion} / \mathrm{cm}^{2}$ ). Importantly, the estimations made on the basis of simultaneous measurements of the total pressure and partial pressure of helium showed that during thermal desorption, e.g., at a temperature of $120^{\circ} \mathrm{C}$ (see Fig. 5), quantity of desorbed helium could be about that for all the rest gases.

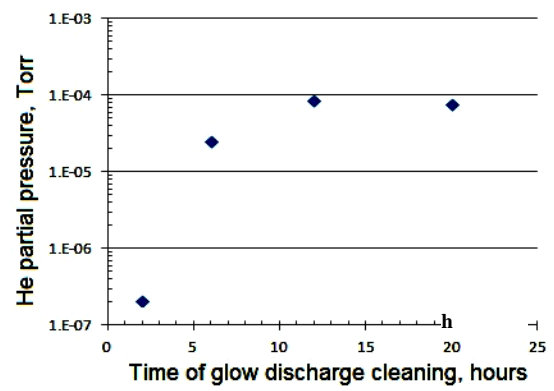

Fig. 9. He release during $S S$ probe pulse heating to the temperature of $300^{\circ} \mathrm{C}$ vs the time of GDC 


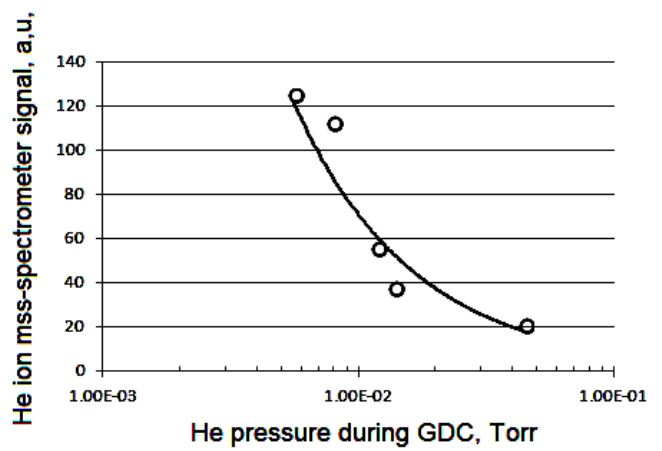

Fig. 10. He release from SS-sample during pulse heating to the temperature of $500{ }^{\circ} \mathrm{C}$ vs $\mathrm{He}$ pressure GDC

Fig. 10 shows the rate of helium outgassing from SS samples when heated to $500{ }^{\circ} \mathrm{C}$ plotted versus the pressure of the discharge gas during GDC. When the pressure changes from $5.6 \cdot 10^{-3}$ to $4.5 \cdot 10^{-2}$ Torr, the outgassing rate of helium gas from the stainless steel decreases by a factor of 6 . Since the amount of desorbed gas (outgassing rate) is proportional to its concentration on the metal surface, one can say that at high pressures of GDC, SS binds less helium than at low discharge pressures. This is most likely associated with a decrease in the ion energy with an increase in the gas pressure. Fig. 11 gives understanding of the kinetics of He release at different heating times (number of heat pulses). It can be seen that the samples treated at high gas pressures are freed from helium faster than the ones in the lower pressure regime. We associate this with a change in the energy spectrum of ions, which, in turn, leads to the changes in the amount of bound gas, the depth of its penetration into the metal, etc. So, if we want to have plasma regime with low He recycling, it is preferable to carry out GDC at high pressure of discharge gas (He). But in this case, a decrease in the cleaning efficiency is possible [5].

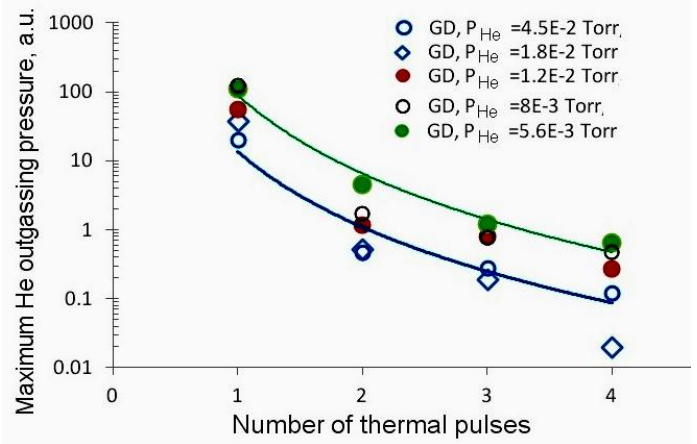

Fig. 11 . He outgassing rate of $12 \mathrm{Cr} 18$ Ni10Ti stainless steel during its heating to the temperature of $300{ }^{\circ} \mathrm{C} v \mathrm{vs}$ number of thermal pulses

\section{SUMMARY AND CONCLUSIONS}

The thermal desorption experiments were carried out to study the process of helium release from the stainless steel $12 \mathrm{Cr} 18 \mathrm{Ni} 10 \mathrm{Ti}$ after its exposure to steady state GD plasma in $\mathrm{He}$ atmosphere. The current-voltage characteristics in different plasma regimes were measured, and estimation of He ions energy was made. Measurements of He outgassing from the SS probes by thermal desorption pulse method showed that the saturation of the probe surface with $\mathrm{He}$ is observed at rather low fluencies $\left(\sim 4 \cdot 10^{19}\right.$ ion $\left./ \mathrm{cm}^{2}\right)$. The value of He outgassing strongly depends on the pressure of the work gas during GDC. In our case, it decreased by a factor of six with the increase in pressure from $5.6 \cdot 10^{-3}$ to $4.5 \cdot 10^{-2}$ Torr. Several maximums were registered in the $\mathrm{He}$ thermal desorption curves that indicated different $\mathrm{He}$ atom states on the surface and in the nearest surface bulk. Noticeable desorption of helium at the temperature of $\sim 100{ }^{\circ} \mathrm{C}$ turned out to be different from the data for the stainless steel SUS316L reported earlier in [3]. The reason may be in the differences in the surface properties of the studied steels (for example, the degree of contamination) and in the features of the techniques and methods.

\section{REFERENCES}

1. H.F. Dylla, S.A. Cohen, S.M. Rossnagel, et al. Glow discharge conditioning of the PDX vacuum vessel // J. Vac. Sci. Technol. 1980, v. 17 (1), p. 286-290.

2. H. Suzuki, N. Ohyabu, A. Komori, et al. The LHD Experimental Group. Behavior of helium gas in the LHD vacuum chamber // Journal of Nuclear Materials. 2003, v. 313-316, p. 297-301.

3. Y. Kubota, N. Noda, A. Sagara, et al. Investigation of the trapped helium and hydrogen ions in plasma facing materials for LHD using thermal desorption spectrometer and alternating glow discharge cleanings // Journal of Nuclear Materials. 2003, v. 313-316, p. 239-244.

4. A. Spring, R. Brakel, H. Niedermeyer. Wall conditioning for Wendelstein 7-X by glow discharge // Fusion Engineering and Design. 2003, v. 66-68, p. 371375 .

5. R.P. Govier and G.M. McCracken. Gas Discharge Cleaning of Vacuum Surfaces // Journal of Vacuum Science \& Technology. 1970, v. 7, p. 552; doi: 10.1116/1.1315874.

6. G.P. Glazunov, M.N. Bondarenko, A.L. Konotopskiy, E.D. Volkov. Erosion behavior of tungsten coatings in magnetron type discharges with hot cathode // Problems of Atomic Science and Technology. Series "Plasma Physics". 2008, N 6(58), p. 107-109.

7. G.P. Glazunov, V.E. Moiseenko, S.M. Maznichenko, et al. Vacuum-plasma properties of stainless steel after impact of combined glow-microwave discharges in argon atmosphere // Problems of Atomic Science and Technology. Series "Plasma Physics". 2021, N 1(131), p. 50-58

8. G.P. Glazunov, V.K. Pashnev. A method for diagnosing the state of the surface of the vacuum chamber of the torsatron Uragan-2M // Physical surface engineering. 2012, v. 10, N 2, p. 173-176.

9. G.P. Glazunov, D.I. Baron, V.E. Moiseenko, et al. Characterization of wall conditions in Uragan-2M stellarator using stainless steel thermal desorption probe // Fusion Engineering and Design. 2018, v. 137, p. 196201.

10. G.P. Glazunov, D.I. Baron, M.N. Bondarenko, et al. In situ quantification of plasma facing surface conditions in the Uragan-2M torsatron // Problems of Atomic Science and Technology. Series "Plasma Physics". 2018, N 1(107), p. 12-16. 
11. E.A. Bakulin, E.Stepin, and V.V. Shcherbinina. Application of the delay method for plasma research // Journal of Technical Physics. 1969, v. 39, N 1, p. 114121.

12. W. Eckstein, C. Garsia-Rosales, J. Roth, W. Offenberger. Sputtering Data. IPP, Garching, Munchen, 1993, p. 342.

13. Y. Yamamyra and H. Taware. Energy dependence of ion-induced sputtering yields from monoatomic solids at normal incidence: Research report NIFS, Data series, NIFS-DATA-23, 1995, p. 114.

14. D.J. Reed. A review of recent theoretical developments in the understanding of the migration of helium in metals and its interaction with lattice defects // Rad. Effects. 1977, v. 31, p. 129-147.

15. A.P. Zakharov. Hydrogen interaction with radiation damages in metals: Dissertation of the doctor of physical and mathematical sciences. M., 1980, 372 p.

Article received 01.04.2021

\section{ГАЗОВЫДЕЛЕНИЕ ГЕЛИЯ ИЗ НЕРЖАВЕЮЩЕЙ СТАЛИ 12Х18Н10Т ПОСЛЕ ОБРАБОТКИ ПЛАЗМОЙ СТАЦИОНАРНОГО ТЛЕЮЩЕГО РАЗРЯДА В АТМОСФЕРЕ ГЕЛИЯ}

\section{Г.П. Глазунов, М.Н. Бондаренко, А.Л. Конотопский, И.Е. Гаркуша, С.М. Мазниченко, И.К. Тарасов}

Проведены термодесорбционные эксперименты по изучению процесса выделения гелия из нержавеющей стали 12Х18Н10Т после воздействия плазмы стационарного тлеющего разряда в атмосфере Не. Измерены вольт-амперные характеристики в различных режимах, и произведена оценка энергии ионов Не. Измерения выхода Не из нержавеющей стали методом импульсной термодесорбции показали, что наблюдается насыщение поверхности зонда гелием при дозах $\sim 4 \cdot 10^{19}$ ион/см². Величина газовыделения Не сильно зависит от режима плазмы: давления рабочего газа, напряжения разряда и т. д. На кривых десорбции Не зарегистрирован ряд максимумов, включая максимум при температуре $100 \ldots 150{ }^{\circ} \mathrm{C}$, указывающих на различные состояния атомов Не на поверхности и в приповерхностном объеме. Обсуждаются физические механизмы такого характера газовыделения Не.

\section{ГАЗОВИДІЛЕННЯ ГЕЛІЮ 3 НЕРЖАВІЮЧОЇ СТАЛІ 12Х18Н10Т ПІСЛЯ ОБРОБКИ ПЛАЗМОЮ СТАЦІОНРНОГО ТЛІЮЧОГО РОЗРЯДУ В АТМОСФЕРІ ГЕЛІЮ}

\section{Г.П. Глазунов, М.М. Бондаренко, О.Л. Конотопський, І.С. Гаркуиа, С.М. Мазніченко, І.К. Тарасов}

Проведені термодесорбційні експерименти по вивченню процесу виділення гелію з нержавіючої сталі 12X18Н10Т після дії плазми стаціонарного тліючого розряду в атмосфері Не. Зміряні вольт-амперні характеристики в різних режимах плазми, і проведена оцінка енергії іонів Не. Вимірювання газовиділення Не 3 нержавіючої сталі методом імпульсної термодесорбції показали, що спостерігається насичення поверхні зонда гелієм при дозах 4.10 19 іон/см². Величина швидкості десорбції Не сильно залежить від режиму плазми: тиску робочого газу, напрузі розряду і т. д. На кривих десорбції Не зареєстровано кілько максимумів, включаючи максимум при $100 \ldots 150{ }^{\circ} \mathrm{C}$, що вказує на різні стани перебування атомів Не на поверхні і в приповерхневому об'ємі. Обговорюються фізичні механізми такої поведінки газовиділення Не. 